\title{
Central Banks Caught Between Market Liquidity and Fiscal Disciplining: A Money View Perspective on Collateral Policy Jakob Vestergaard and Daniela Gabor*
}

\author{
Working Paper No. 170
}

December $1^{\text {st }}, 2021$

\begin{abstract}
Despite much attention to unconventional monetary policies after the financial crisis, the collateral policies of central banks are rarely discussed. And when they are, the haircuts applied to assets pledged to access central bank liquidity tend not to be analyzed. An exception to these trends is the recent work by Nyborg (2017), who argues that the collateral policies adopted by the European Central Bank (ECB) aggravated the sovereign debt crisis and put the survival of the euro at risk. Taking our point of departure in the money view literature (Mehrling 2011), we argue however that Nyborg's critique of the ECB's crisis response is misguided and that his proposal to deepen and reinforce the ECBs role in the fiscal disciplining of member states would be procyclical and destabilizing. Through our analysis of Nyborg's work and the ECBs crisis response, we identify core principles for countercyclical collateral policies suitable for market-based financial systems.
\end{abstract}

\section{https://doi.org/10.36687/inetwp170}

Keywords: Central banks, collateral policy, fiscal disciplining, financial stability, haircuts.

JEL Classifications: E42, E58, F45

\footnotetext{
* Jakob Vestergaard is Associate Professor at Roskilde University (javest@,ruc.dk) and Daniela Gabor is Professor at the University of West England. The paper draws upon research funded by the Institute for New Economic Thinking (INET). Comments on a previous version of this paper from Charles A.E. Goodhart and Perry Mehrling are gratefully acknowledged.
} 
Central banking is widely seen as first and foremost a matter of using interest rates to achieve monetary policy goals. Central banks lend not merely at a cost, however, but always against securities. Borrowers pledge assets to access central bank funding and in this sense the lending is secured. ${ }^{1}$ The principles that guide central banks in deciding what assets to accept as collateral in their secured lending and what haircuts to apply are increasingly important to financial stability. ${ }^{2}$

When the European Central Bank (ECB) launched its Pandemic Emergency Purchases Program (PEPP) in early spring 2020, it was accompanied by important adjustments of its collateral policy (Vestergaard and Gabor, 2019a). In two successive steps, the ECB loosened the terms by which it lends money to banks. On April 7, it decided to reduce its haircuts by 20\%, thereby substantially increasing the liquidity banks can mobilize for a given amount of collateral. And on April 22, the ECBs collateral policy was further eased by its decision to lower the credit rating threshold for asset eligibility by two notches, from BBB- to B-.

So far collateral policy has been afforded little attention by central banking scholars. The relative neglect of collateral policy was always a peculiar omission, but with the increasing integration of money and capital markets from the 1980 s onwards even more so. Today, the collateral practices of central banks are critical to financial stability.

Nyborg's (2017) book on the collateral frameworks of central banks is the first comprehensive effort to articulate the role of collateral policy in central banking, addressing the "structure, functionality, role, reach and implications of collateral frameworks" as phenomena that are increasingly central to the way that our monetary and financial system operates (Nyborg 2017: xiv). ${ }^{3}$ His analysis focuses on the collateral framework of the European Central Bank (ECB), which he finds particularly intriguing because of Europe's "banking and sovereign debt problems" (ibid.), but he claims wider relevance for his findings.

The main message of Nyborg's book is that the terms on which ECB exchange money for collateral are too detached from market valuations of collateral and "overly generous" (Nyborg 2017: 257). Nyborg acknowledges that this may have served the purpose of easing the constraints caused by having a "single currency for disparate economies", with liquidity being channeled to "where it is needed" (Nyborg 2017: 20). However, for Nyborg this liquidity expedience comes at too high a price; it results in a systematic

\footnotetext{
${ }^{1}$ On central bank collateral frameworks, see BIS (2013, 2015) and Vestergaard and Gabor (2019a:2-3); for comparative perspectives, see ECB (2013a) and Cheun et al (2009); for a historicizing perspective, see Boy and Gabor (2019).

${ }^{2}$ The term haircut has several meanings in finance, but there is no clear etymology. The first uses in finance appear to date back to the 1880s. Some speculate that the loss one takes relative to market value - whether on a debt restructured or a collateral pledged - is described as a 'haircut' to indicate a loss of power and prestige, and ultimately (if the haircut is very large) as a shorthand for being (financially) beheaded. For introductions to central bank haircuts, see Bank of Canada (2011) and Chapman et al (2011).

${ }^{3}$ Nyborg's book and the working paper that preceded it (2016), has been discussed in a short commentary by Bindseil and Laeven (2017). See also Campiglio et al (2018), Chesney (2018), and van Bekkum et al (2017).
} 
undermining of market discipline, to the detriment of fiscal prudence, efficient resource allocation and economic growth.

Discussing the ECB's response to the European sovereign debt crisis, Nyborg puts forward two key assertions and a policy proposal. First, he asserts that the ECB's monetary policies were too accommodative, including its collateral policies, effectively disincentivizing banks and governments in distressed countries from prudently restraining their borrowing. Second, he argues that the ECB's crisis response was largely ineffective and that its protracted liquidity injection strategy had disconcerting consequences for the ECB's balance sheet, with perplexing implications for the credibility of the euro. The ECB's collateral policies played a central role, Nyborg argues, but they also hold the key to rectifying the predicament. If haircuts were designed to increase as fiscal deficits and public debt drift away from agreed thresholds, the ECB could accomplish a highly desired disciplining effect on governments. ${ }^{4}$

While we acknowledge that the ECBs liquidity provision in the years preceding the Outright Monetary Transactions (OMT) program was accommodative, we argue that Nyborg's characterization of the ECBs collateral policy in this period is misleading. In fact, enhanced liquidity provision was accompanied by collateral contraction, not by (consistently) accommodative collateral policy. Beyond this empirical misnomer, the main problem with Nyborg's work is that his policy proposal amounts to launching a regime of disciplinary haircuts that would undermine financial and monetary stability. But before we elaborate that point, two important clarifications need to be made. First, there is already a disciplinary feature in the ECBs collateral policies - albeit a less comprehensive one - originating in developments in and around the Stability and Growth Pact in 2005. Second, in the recent collateral easing undertaken by the ECB in response to the COVID-19 pandemic, this disciplinary feature was sharpened (Vestergaard and Gabor, 2019a). The real question is whether to further deepen and reinforce the disciplinary role of the ECBs collateral policies, in other words, not whether to now introduce it. ${ }^{5}$ We argue in favor of the opposite strategy: if collateral markets are showing signs of strain, countercyclical haircut changes may help abate them, potentially preventing the eruption of a market liquidity crisis.

After a primer on collateral policy (section 2) we examine Nyborg's critique of ECBs crisis response, challenging his notion that its collateral policy had been overly generous (section 3). Following this, we summarize the key features of his proposal for a new mode of disciplinary collateral policy (section 4). Assessing his proposal and looking forward, we argue that Nyborg's proposal amounts to a shift from a binary to a generalized mode of disciplinary collateral policy that would be procyclical and destabilizing - and we identify a set of principles for central banking collateral policies that would be more likely to stabilize market-based financial systems (section 5). In so doing, we address an important gap in the existing literature. Most scholarship on unconventional monetary policy focus on negative interest rates

\footnotetext{
${ }^{4}$ Nyborg is the leading exponent of disciplinary haircuts, but other scholars have made similar arguments, see Orphanides (2017: 12): "a graduated schedule of haircuts based on indicators of fiscal fundamentals could be applied. For example, haircuts could be increasing in a member state's debt-to-GDP ratio".

${ }^{5}$ On the ECB's implicit austerity mandate, see Vestergaard and Gabor (2019b).
} 
and various forms of quantitative easing but overlook collateral policy. And the few studies that do examine collateral policies, focus on asset eligibility and counterparty access, but ignore the haircut schedules that define the terms by which collateral assets are accepted in central bank credit operations. ${ }^{6}$

Both in examining Nyborg's critique of the ECB and his proposed mode of disciplinary central banking, and in seeking out principles for collateral policy suitable to market-based financial systems, we mobilize and contribute to the money view literature on market liquidity. ${ }^{7}$ Apart from contributing to key conversations in the emerging field of critical central banking studies, we hope to stimulate policy reflections on potential new directions for the collateral frameworks of central banks.

2

\section{A PRIMER ON COLLATERAL POLICY}

Pawnbroker practices in Ancient Greece - where borrowers posted collateral with a pawnbroker to access loans - was an early form of secured lending. While secured lending exists in many forms, one feature is a constant: what is accepted as collateral varies significantly over time (see Vestergaard and Gabor 2019a: 2-4). This holds for central bank lending too. What the European Central Bank (ECB) accepted as collateral before and after the financial crisis was two altogether different things. When money and credit markets are liquid and well-functioning, central banks take a conservative approach, accepting only high-quality assets as collateral. ${ }^{8}$ In periods of market stress, on the other hand, it usually responds to its (explicit or implicit) mandate for preserving financial stability, by accepting a wider range of assets as eligible collateral for its open market operations.

Overall, three core factors define the contours of central bank collateral policies (BIS 2015). First, eligibility criteria set out what assets are eligible as collateral when banks seek access to central bank money; second, haircuts determine how much central bank money a bank will receive (in percentage of the market value of the collateral) for different types of eligible collateral and, third, stipulations on counterparty access define what types of financial institutions the central bank is willing to provide lending to.

The ECB is generally seen to accept a broad range of collateral and have a comparatively large number of counterparties in its credit operations (BIS 2014). ${ }^{9}$ Haircuts are of particular relevance to our concerns, however. The haircut denotes the difference between the market value of the collateral a bank pledges to

\footnotetext{
${ }^{6}$ This characterization applies to contributions in this journal too. Le Maux and Scialom (2013) discuss collateral eligibility without mentioning haircuts - and contributions by Argitis (2017), Bibow (2013), Dow (2017), Fiebiger and Lavoie (2021) also to do not address the role of haircuts in central bank crisis policies.

${ }^{7}$ Core contributions include Gabor (2016); Gabor and Vestergaard (2016); Mehrling (2011, 2012, 2014); Mehrling et al (2014), and Pozsar (2014).

${ }^{8}$ The collateral framework of the ECB in the early 2000s may be considered an exception from this general rule, see the discussion in section 3 .

${ }^{9}$ The specifics of the ECB collateral framework are closely linked to the process of merging the practices of many national central banks into a single, unified collateral framework prior to the establishment of the euro (Galvenius and Mercier, 2011).
} 
the central bank, and the loan that the central bank will give in exchange. The haircut can be seen as the central banks' insurance against liquidity risk. Should the borrower be unable to pay back the loan, the central bank can avoid a net loss even if it has to sell the collateral at price below the original market value; "assets can go up and down in value and central banks may need some time to sell specific assets" and hence the haircut therefore "provides a kind of safety buffer against any loss in value" (ECB 2016b).

Haircuts for the highest quality collateral are as low as $0.5 \%$, reflecting that for some types of collateral the liquidity risks associated with the asset is considered to be almost non-existing. ${ }^{10}$ For most central banks, this applies to government bonds and central bank bills, which are considered the safest forms of assets because bond-issuing governments have recourse to the tax collection capacities of the state and central banks to the issuance of money.

Generally, haircuts are higher the less liquid the asset and the lower its credit quality. In this sense, haircuts are first and foremost a risk management technique for central banks. But since the global financial crisis, it has become apparent that haircuts have important implications for market liquidity (Gabor and Ban, 2016; Chapman et al, 2011). For most central banks, however, "the main driver of their haircut policy is risk management, and not the broader goal of providing liquidity to the market" (BIS 2015: 24).

3 THE ECB'S COLLATERAL POLICIES BEFORE AND AFTER THE CRISIS

When the fiscal thresholds of the Maastricht treaty were breached by Germany and France in the early 2000s, calls were made for the ECB to step up where member states had fallen short; the ECB was encouraged to use its collateral policies to achieve the fiscal disciplining that other European institutions had not. Proponents of market-based economic governance purported that the disciplinary forces of the market had been blunted by the ECB's collateral policies. For several commentators, the uniform treatment of member state government bonds in ECB credit operations the ultimate culprit for fiscal indiscipline (Buiter and Sibert 2006; Fels 2005a, 2005b; see also Fitoussi 2005 and Wyplosz 2005). Only the ECB's uniform treatment of sovereign debt could plausibly explain the concurrence of wildly different fiscal fundamentals for different eurozone countries and nearly non-existing yield differentials on their government bonds following the inception of the EMU (Buiter and Sibert 2006: 10).

The policy of not differentiating between the debts of EU member states originates in the establishment of the ECB and was motivated by the political ambition to create a 'single' European market in government bonds. The ECB was not allowed to purchase the government debts of member states since this would be seen to compromise the principle that the ECB should never 'monetize' the public expenditures of any member state. Monetary policy implementation by the ECB therefore focused on

\footnotetext{
${ }^{10}$ Other assets face much higher haircuts. For instance, if a bank pledges asset-backed securities as collateral, it could face a haircut of 20 or $50 \%$, depending on the residual maturity of the asset and other risk factors.
} 
secondary markets and to large extent consisted in short-term repurchase agreements (repo) secured by government debt. Repo market integration thus became essential to monetary policy. The uniform treatment of sovereign debt was intimately related to the notion that unified repo markets in government bonds would be highly conducive to monetary policy effectiveness as well as to financial integration more generally. ${ }^{11}$ Repo-driven financial integration was seen, in turn, as crucial in spurring a wider process of gradually increasing political integration.

For critics of the uniform treatment of EU member state government bonds, however, collateral policies predicated on these unification ideals were bolstering the market value of government bonds with low credit quality and were hence effectively undermining fiscal discipline and by extension the credibility of the European and Monetary Union.

From the perspective of this criticism, the solution was straightforward. If the ECB's collateral framework had constituted an implicit subsidy in the form of too low haircuts for the debts of sovereigns with poor fiscal fundamentals - "misleading" markets not to differentiate between the default risks of the bonds of different eurozone sovereigns - the obvious way forward would be to quickly do away with equal treatment of sovereign debt. Buiter and Sibert recommended introducing haircuts on government bonds that were differentiated in accordance with their credit rating. Government bonds with an AAA rating would be assigned the lowest haircut, those with an AA-rating would be subject to the second lowest haircut, and A-rated sovereign debt to the third lowest haircut, and so forth (Buiter and Sibert 2006: 27).

Despite initial resistance, the ECB soon yielded (Orphanides 2017). In November 2005, the ECBs collateral framework was reformed, although in much less granular form than its critics had wished for. From 2006 onwards, government bonds would be eligible in credit operations with the ECB only if they had a credit rating of at least A-. Sovereign debt rated lower than that by credit rating agencies would be ineligible altogether. It was envisaged that this would constitute a strong incentive on member states to avoid fiscal imprudence.

Nyborg does not discuss this first introduction of disciplinary collateral policy. But it is an important backdrop to our analysis of his work. One may see his policy proposals as a suggestion to replace a binary form of disciplinary collateral policy (i.e., eligibility subject to a threshold, below/above) with a generalized and continuous regime of disciplinary haircuts (in accordance with degrees of deviation from a threshold).

\footnotetext{
${ }^{11}$ On the institutional specifics of monetary policy implementation by the ECB, see Bindseil $(2005,2014)$. On the project of creating unified European repo markets, see the Giovanni Group (1999) and ECB (2002).
} 


\subsection{The ECBs crisis response: Nyborg's critique}

Nyborg builds his case for a new mode of disciplinary central banking on a critique of the ECB's crisis response. Nyborg's two main criticisms are that the ECB's lending was too generous and that it failed to devise collateral policies that would engender proper market discipline on banks and governments.

Nyborg's core claim is that the ECB's combination of expanded collateral eligibility and too generous haircuts encouraged fiscal imprudence by indebted member states, ultimately threatening the survival of the euro. "By allowing central bank money to be issued against sovereign debt at overly generous terms", the ECB "helped lower the funding costs for these more indebted nations" (Nyborg 2017: 257) effectively encouraging them to keep lending rather than put their houses in order. Greece and Italy, in particular, caused "great hardship on the rest of the euro area, and indeed the global economy", Nyborg argued, because their ever-increasing indebtedness made "the threat of default credible" (2017: 254).

Following the collapse of Lehman Brothers in September 2008, the ECB had adopted what Nyborg labelled a "super-accommodative" monetary policy (2017: 45). The introduction of unlimited refinancing operations with extended maturities was particularly significant, he argued, because they "provided banks with almost unlimited funding from the central bank, constrained only by banks' eligible collateral holdings" (Nyborg 2017: 23). And even the collateral constraint was soon relaxed, Nyborg noted. Although the ECB's collateral eligibility rules were already "fairly relaxed", they were further relaxed over the course of the crisis (Nyborg 2017: 60).

The shortest route to broadening the collateral framework was by lowering the minimum threshold for asset eligibility. ${ }^{12}$ This is exactly what the ECB did. In late October 2008, only weeks after Lehman Brothers collapsed, it lowered its minimum credit rating threshold from A- to BBB. A second expansion of eligible collateral occurred in the context of the long-term refinancing operation (LTRO) undertaken in early 2012. The ECB decided to admit more than 10,000 new securities to the public list of eligible collateral. Data on which banks used this round of ECB liquidity strongly suggest that the inclusion of unsecured bank debts was "part of an overall package to support, or indirectly bail out, banks" in Spain, Italy and France (Nyborg 2017: 177).

By easing up its already quite relaxed collateral eligibility criteria in these ways, the ECB was entering dangerous territory, Nyborg bemoaned. From 2004 to 2013, the nominal value of eligible marketable collateral nearly doubled from 7.5 to 14.2 trillion euros (Nyborg 2017: 54). Further, as a consequence of its liquidity interventions, the ECB's balance sheet expanded from 1 trillion in 2006 to 2.3 trillion euros in 2013 (i.e., from 13 to $24 \%$ of euro-area GDP), with a considerable, consequential decline in the average quality of assets accepted (ibid.).

\footnotetext{
${ }^{12}$ For purposes of assessing collateral pledged, the ECB classified all assets in three categories: assets with a credit rating between AAA and A- were considered high quality; assets with a rating from $\mathrm{BBB}+$ to $\mathrm{BBB}$ - were deemed medium quality; assets with a credit rating lower than BBB- were considered low quality, and not eligible as collateral with the ECB.
} 
Nyborg then invokes Klaas Knot, head of the Dutch Central Bank, to pinpoint the deeper implications. As of result of the ECB's liquidity injections, Eurosystem balance sheets were "becoming more and more exposed to economic risk and political pressure" (Nyborg 2017: 13). "Eventually", warned Nyborg (citing Knot), this could "result in a substantial amount of negative capital in a central bank's balance sheet", potentially undermining its "credibility and independence" (ibid.).

The ECB's strategy of abundantly accommodating the liquidity needs of banks was not just dangerous, however. It was also largely unsuccessful, Nyborg stressed. Even after having shifted to liquidity provisioning without rationing ("full allotment"), and after increasing maturities twelve-fold (from 3 months to 3 years), stress in government bond markets failed to abate. When unlimited amounts of longmaturity liquidity proved inadequate to calm the markets, the ECB's liquidity expansion strategy could hardly be said to have been successful.

\subsection{ECB lending was not overly generous}

The ECB had provided too much liquidity, at too generous terms, Nyborg concluded. By the end of 2013, haircuts had "never been lower over the almost eleven-year period studied" (Nyborg 2017: 84). But although the ECB did indeed vigorously provide liquidity to European banks, it did so while at the same time sharply raising its haircuts for assets with a low credit rating, whether (peripheral) government bonds or unsecured bank debts.

From late 2004 to early 2014, the ECB made major changes to its haircut schedule at three junctures: 25 October 2008, 1 January 2011, and 1 October 2013. While Nyborg discuss these changes in some detail, he mischaracterizes them. To demonstrate this, we launch the notion of haircut differentials, understood as the spread between haircuts on collateral assets with a high and a low credit rating.

Before October 2008, the ECB applied identical haircuts to all European government debt. There was no distinction between high- and low-quality collateral in this asset class. After the collapse of Lehman, the haircuts on highly rated government debt remained at the same level, while all of lower rated government debt was assigned haircuts that were 5 percentage points higher. Overall, three observations about changes made by the ECB to its haircut schedule stand out (see Table 1):

First, haircuts for high quality collateral were kept low throughout the crisis (and even declining for longer residual maturities). Second, for government bonds with a low credit rating the opposite trend prevailed. Assets with a low rating faced a dramatic increase in haircuts, in the range of 550 to 850 basis points (depending on residual maturities), seen over the full period. ${ }^{13}$ Third, the haircut spread - between assets with a low (B to BBB-) and a high credit rating (A to AAA) - jumped 500 basis points in October 2008, was unaffected by the January 2011 revision, but increased again in October 2013, with 50 to 400 basis points (depending on residual maturities).

\footnotetext{
13 The haircut increased from 0.5 to $6 \%$ for government bonds with a residual maturity of less than a year; and from 4.5 to $13 \%$ for government bonds with a residual maturity of between 7 and 10 years (cf Table 1).
} 
Over the full period, haircuts on government bonds with a low credit rating and residual maturity of less than one year were increased 12-fold, from $0.5 \%$ to $6 \%$, whereas haircuts for the same class of government bonds with a residual maturity of $7-10$ years nearly tripled, from $4.5 \%$ to $13 \%$. These are hardly trivial increases.

Table 1 Haircuts on government bonds (in \% of market value of the collateral) ${ }^{14}$

\begin{tabular}{|l|l|l|l|l|}
\hline & $\begin{array}{l}\text { Before Sept 2008 } \\
\text { High CR-Low CR } \\
\text { HD) }\end{array}$ & $\begin{array}{l}\text { Oct 08-Dec 2010 } \\
\text { High CR-Low CR } \\
\text { (HD) }\end{array}$ & $\begin{array}{l}\text { Jan 2011- } \\
\text { Sept2013 } \\
\text { High CR-Low CR } \\
\text { (HD) }\end{array}$ & $\begin{array}{l}\text { Oct 2013- } \\
\text { High CR-Low CR } \\
\text { (HD) }\end{array}$ \\
\hline RM: 0-1 & $0.5-0.5(0)$ & $0.5-5.5(500)$ & $0.5-5.5(500)$ & $0.5-6(550)$ \\
\hline RM: 1-3 & $1.5-1.5(0)$ & $1.5-6.5(500)$ & $1.5-6.5(500)$ & $2-8(600)$ \\
\hline RM: 3-5 & $3-3(0)$ & $3-8(500)$ & $2.5-7.5(500)$ & $2.5-10(750)$ \\
\hline RM: 5-7 & $3.5-3.5(0)$ & $3.5-8.5(500)$ & $3-8(500)$ & $3-11.5(850)$ \\
\hline $\begin{array}{l}\text { RM: } 7- \\
\text { 10 }\end{array}$ & $4.5-4.5(0)$ & $4.5-9.5(500)$ & $4-9(500)$ & $4-13(900)$ \\
\hline RM: > 10 & $8.5-8.5(0)$ & $8.5-13.5(500)$ & $5.5-10.5(500)$ & $7-16(900)$ \\
\hline
\end{tabular}

Note: $\mathrm{RM}=$ residual maturity; $\mathrm{CR}=$ credit rating; $\mathrm{HD}$ : haircut differential, in basis points

We have demonstrated elsewhere that the same pattern applies to haircut changes on the debt instruments of banks (Vestergaard and Gabor (2019c). One brief observation can be highlighted here. For short maturities, haircuts increased roughly three-fold for highly rated assets in this category, but more than seven-fold for assets with a low rating. ${ }^{15}$

We suggest that these haircut changes do not match their depiction by Nyborg as "overly generous". On the contrary, it is difficult to imagine that haircut increases at this scale did not add substantially to the already severe liquidity strains of troubled banks and governments in distressed countries.

\subsection{Too little market input in the ECB collateral policy?}

Nyborg laments the infrequency of ECB haircut changes. The average time between each new haircut table was effectively more than three years, he notes. For some securities the haircuts even remained the same "throughout the 3493-day period" on which his analysis focused (Nyborg 2017: 85). Apart from these infrequent updates to the haircut schedule, "the only events that bring about a haircut change for an individual security", Nyborg observes, are "the yearly reduction in residual maturity" and "a possible

\footnotetext{
${ }^{14}$ Haircuts cited are all for zero coupon. Data on ECB haircuts are from ECB (2008, 2010, 2011, 2013b, 2013c, 2017c) and Nyborg (2017: 66-77, 281-292). See also Wolff (2014).

${ }^{15}$ On the short maturity spectrum there was a substantial increase of the haircut from 2 to $6.5 \%$ for highly rated assets in this category in 2008, but after that no changes. But for short maturity assets with a low credit rating, the haircuts increased from 2 to $11.5 \%$ in 2008, then to $15 \%$ in January 2011.
} 
ratings change should the security's rating fall below A- or BBB- " (ibid.). Given that both these changes to the ECB's haircuts are infrequent, the only "direct input from the market itself to a security's collateral value in Eurosystem operations", is "the market price, if any, of the collateral" (ibid.). The upshot, Nyborg concludes, is that "markets are utilized" only to a "small degree" in the ECB's collateral framework (2017: 178).

When the amount of central bank money that a bank can obtain from the ECB against
collateral is influenced only to a limited extent by market forces, market discipline is
systematically undermined, Nyborg argues, and as a result money and asset markets
are systematically distorted. In fact, "it appears that many features of the framework
are designed to circumvent market discipline", Nyborg ponders (2017: 178). ${ }^{16}$

But the criticism that the ECB's collateral policy lacks market inputs is off target. At the heart of the ECB's collateral policy are daily collateral valuation and margining practices. These practices are operated to ensure that the amount and quality of collateral is continuously adapted to reflect changing market perceptions of credit, counterparty and liquidity risk, to "protect the Eurosystem against the risk of financial loss if underlying assets have to be realized owing to the default of a counterparty" (ECB 2017a). If the market value of an asset pledged to access central bank liquidity falls, the ECB will demand that the bank pledges more collateral - so as to continuously ensure that the market value of the collateral pledged matches the liquidity provided to the bank.

Nyborg's representation of the ECBs collateral policies does little justice to these daily practices of aligning accepted collateral with market valuations. We surmise that Nyborg's insistence that there was too little market input in the ECB's collateral policies during the crisis, reflects a fundamental, conceptual shortcoming. Throughout his book, Nyborg fails to distinguish between what is required of central bank collateral policies in normal times and times of crisis. This is particularly striking given that the distinction is standard in the literature on the collateral policies of central banks. "In crisis times", the Bank of International Settlements (BIS) notes, "collateral acceptance typically becomes more conservative in private markets, and the pool of assets deemed suitable as collateral shrinks as the perceived risk of assets and counterparties rise" (BIS 2015: 5). Under circumstances of financial distress, the very point of central bank operations is to accommodate the "greater scarcity of collateral", BIS stresses (ibid.). One of the key ways of doing this, is to launch "facilities that allow banks to post illiquid collateral assets in place of liquid securities that, in turn, can be used to obtain funding in the private market" (BIS 2015: 2, emphasis added). If central banks instead replicated the conservatism of markets, as Nyborg advocates, the effect would be procyclical and destabilizing, as we discuss below.

\footnotetext{
${ }^{16}$ Nyborg identifies no less than 14 aspects of the ECB's collateral requirements that "impair market forces and market discipline" (2017: 178-191). To highlight a few: non-marketable assets are included in the set of eligible collateral; a substantial fraction of eligible collateral is based on 'theoretical prices', as opposed to market prices; and when market prices are finally used, they are often 'stale' (i.e, up to five days old).
} 


\section{NEW REGIME FOR COLLATERAL POLICY: DOUBLING DOWN ON FISCAL DISCIPLINING}

Two decades after the signing of the Maastricht treaty, thresholds for fiscal deficits and public debts are still not being met by most member states, Nyborg notes. "Despite a no-bailout clause in the Maastricht Treaty", bailouts of member states have become "an integral part of the fabric of the euro" (Nyborg 2017: 246). While the ECB's crisis response and its collateral policies cannot be held entirely accountable, they have contributed fatally, Nyborg argued, by making the cost of borrowing far too low for the governments of distressed countries.

There is a silver lining, however. Collateral policies can be designed so as to contribute crucially to the prevention of central bank-facilitated over-borrowing in the future. Instances of over-borrowing can be prevented by using haircuts to discipline countries to adhere to agreed debt and deficit thresholds. "The idea is simple", Nyborg says: "if a debt-to-GDP ratio of no more than 60 percent is desired", all you have to do is "increase haircuts progressively in the debt-to-GDP ratio beyond this" (ibid.). The same mechanism can be established for fiscal deficits, such that haircuts are increased progressively as fiscal deficits exceed the agreed threshold. ${ }^{17}$

"My proposal works", explains Nyborg, "by reducing the liquidity and value of a highly indebted country's bonds" (ibid.). The effect is to increase borrowing costs, thereby reducing the "appetite" for borrowing in excess of agreed thresholds. The disciplining effect is contingent on the scale of the haircut discrimination, of course. Only if the increases in haircuts are substantial, will the disciplinary effect be significant, Nyborg notes. The uniqueness and strength of the proposal, in Nyborg's view, stems from the fact that it will effectively rein in the power of sovereigns by carefully deploying the supranational status of the ECB. After that, Nyborg assures, "markets will do the rest" (2017: 258). ${ }^{18}$

5

DISCIPLINARY HAIRCUTS WOULD BE DESTABILIZING

The disciplinary feature installed in the ECBs collateral framework from 2006 onwards was a binary one. There was a marked penalty for government bonds with a credit rating below the minimum threshold; such sovereign debt would no longer be eligible in ECB credit operations. But the disciplinary system proposed by Nyborg differs fundamentally in two ways. First, the suggested disciplinary mechanism is haircuts rather than asset eligibility. And second, the disciplinary mechanism is not binary and exceptional, but generalized and continuous; haircuts are to be differentiated along a spectrum, depending on the degree of deviation of a sovereign from agreed thresholds for fiscal deficits and public debt. ${ }^{19}$

\footnotetext{
${ }^{17}$ In fact, one might consider raising the haircuts even before threshold levels are breached, so as to further increase "the incentives for member states to adhere to the maximum levels" (Nyborg 2017: 257).

${ }^{18}$ In passing, Nyborg discusses using haircuts on collateral as a disciplining device on private banks too (2017: 261).

${ }^{19}$ On the distinction between binary and generalized modes of disciplinary power, see Vestergaard (2004, 2009).
} 
The question is whether such a deepened and generalized disciplinary role for collateral policy would be a good way forward. We argue the contrary to be the case. If haircuts were proportional with fiscal deficits and public debt to GDP (by a rule-based, automatic mechanism), collateral policies would exert a procyclical and destabilizing influence not just on collateral markets, but on the financial systems they anchor. To make our case, we draw upon the money view literature on central banks and collateral markets.

\section{$5.1 \quad$ The money view}

Discussions about central banking often focus on interest rates or asset purchases, whereas the terms under which lending is provided are scarcely discussed. And when discussed, it is rarely from a market liquidity perspective. But we argue that better understanding the links between the different instruments of collateral policy, on one side, and market liquidity on the other, is in fact crucial for post-crisis efforts to rethink central banking (Bini Smaghi 2010; de Grauwe 2011; Eichengreen et al 2011; Goodhart et al 2014; Tucker 2014).

Addressing these issues from a money view perspective means taking point of departure in four core assumptions about contemporary monetary and financial systems. ${ }^{20}$ First, actors in the financial and monetary system are subject to a daily settlement constraint. Second, private dealers play a core role in the formation of asset prices in capital markets and hence in supplying market liquidity. Third, money markets and capital markets are closely intertwined through collateral asset valuations. Fourth, all financial instruments from securities and bank deposits at one end, to currency and gold at the other, are constitutive elements of money hierarchies and subject to vertical convertibility, with gold as the most liquid asset and securities as the least liquid.

From a money view perspective, the interventions of central banks are seen as either providing elasticity or enforcing discipline on the system (Mehrling 2015, 2016). The core distinction, one might say, is between policies that expand or contract market liquidity. The traditional issue of ameliorating funding liquidity problems in the financial sector recedes to secondary importance, in this perspective, relative to the challenge of preventing the eruption of market liquidity crises. ${ }^{21}$

In market-based financial systems collateral values are key to market liquidity. "A key lesson of the crisis", says Perry Mehrling, is that supplying "funding liquidity is not enough, since in a crisis funding liquidity does not get translated into market liquidity, no matter how hard (the central bank) works to push funds out the door" (Mehrling 2011: 137). The role of "translating" funding liquidity into market liquidity is normally a function performed by profit-seeking private dealers, but when private dealers

\footnotetext{
${ }^{20}$ On the money view, see Mehrling (2011, 2012, 2013a, 2013b, 2014, 2015, 2016).

${ }^{21}$ On funding vs market liquidity, see Brunnermeier and Pedersen (2009). In Hauser's phrasing (2021:5), market liquidity refers to "ability to transact in reasonable size at or close to mid-market prices prevailing prior to the trade".
} 
stop performing this function - as they do in a market liquidity crisis - the central bank should step in and become the market-maker of last resort. ${ }^{22}$

Traditional lender of last resort funding (BIS 2004; Winckler 2014) to financial institutions may buy time, but ultimately the only way a central bank can address a market liquidity crisis, is by committing to put a floor under the value of the securities subject to a liquidity spiral. The best way to do so, is by intervening in the markets where banks fund themselves, backstopping the values of core assets used by banks to obtain funding in money markets. When central banks engage in such practices, "trading freely at a wide bid-ask spread, against good security in the money market and in the class of good securities in the capital market", it amounts to the modern equivalent of high interest rates in Walter Bagehot's classic dictum (Mehrling 2014: 110).

Such interventions may "prevent a liquidity spiral from destabilizing the price of those assets" and help avoid undermining "their use as collateral in the market-based credit system" (Mehrling 2012: 111). If the market values of core collateral assets can be stabilized through central bank interventions in repo markets, then the market liquidity of those assets will be restored, to the benefit of funding liquidity too.

\subsection{The role of collateral policy in central bank liquidity management}

To backstop collateral asset values in a market liquidity crisis, a central bank may have to engage in direct purchases of collateral assets, not least government bonds. But asset purchases may not always be necessary, for two distinct reasons. First, commitment to asset purchases may go a long way. Much of the impact of interventions targeting liquidity spirals in collateral markets, "comes not from the actual positions taken by the central bank", Mehrling notes, "but rather from the price support provided by trading options that may well remain unexercised and so never show up on the central bank's balance sheet" (Mehrling 2012: 111). This is what happened when the ECB committed to backstopping the collateral values of European government bonds. Without ever actually activating the Outright Monetary Transactions (OMT) program, Draghi's commitment to intervene (ECB 2012) almost instantly stabilized European government bond markets (Gabor and Ban 2016).

Second, the collateral policies of central banks - if devised with this objective in mind - may in themselves significantly affect market liquidity, and potentially halt a collateral devaluation spiral. By increasing the range of assets eligible in their credit operations, central banks exert an expansionary effect on market liquidity (if eligibility is decreased, a contractionary effect would result). Haircuts, on the other hand, have a contractionary effect if they are increased, and an expansionary effect when they are lowered. If these two key tools of collateral policy are calibrated consistently, with the objective of

\footnotetext{
${ }^{22}$ For discussions of market-making of last resort (MMLR), see Bank of England (2015); Buiter and Sibert (2007); Dooley (2014); Gabor (2016); Hauser (2021) and Mehrling (2011). For a skeptical perspective, see Sissoko (2014). The literature is divided on the definition of MMLR; some argue that there are two ways central banks can perform this role - by outright purchases of securities and/or by accepting an expanded range of securities as collateral (Buiter and Sibert 2007, Mehrling 2011); others argue that only actual purchases of securities qualify (Gabor 2016, Hauser 2021).
} 
enhancing market liquidity, a stabilization of collateral values may be accomplished even without actual asset purchases. However, if not carefully calibrated but instead put to the service of different objectives, changes in the parameters of these two policy instruments may also work against one another, making it difficult to discern the net effect on market liquidity (see Table 2).

Table 2 Market liquidity effects of collateral policy

\begin{tabular}{|c|l|c|c|}
\hline \multicolumn{2}{|c|}{} & \multicolumn{2}{|c|}{ Haircuts } \\
\cline { 3 - 4 } \multicolumn{2}{|c|}{} & Lower & Higher \\
\hline \multirow{2}{*}{$\begin{array}{c}\text { Collateral } \\
\text { eligibility }\end{array}$} & Broader & Expansion & $-/+$ \\
\cline { 2 - 4 } & Narrower & $-/+$ & Contraction \\
\hline
\end{tabular}

If the central bank increases its haircuts - perhaps motivated by concerns over the risks accumulated on its own balance sheet - this will have contractionary effect on market liquidity and may at worst dominate the expansionary effect of a prior broadening of collateral asset eligibility. Ambivalent collateral policy, in the context of a looming market liquidity crisis, likely will aggravate matters - as it did in the ECBs response to the European sovereign debt crisis.

The main points with respect to the collateral policies of central banks in a market liquidity crisis, as seen from a money view perspective, are as follows. First, the key to abating an impending market liquidity crisis is that central banks convince markets that the values of key collateral assets are backstopped by the central bank. Second, haircuts are an integral element of money hierarchies; without them, securities would not be convertible into bank money through repos. In normal times, central banks rightly use them to manage credit and liquidity risks on its own balance sheet, but when market liquidity is showing signs of strain, haircuts should be used as a signaling device; by lowering them - and by narrowing haircut differentials - central banks communicate to markets that they support the value of core collateral assets. Third, while the convertibility of assets with different degrees of moneyness depends on intricate mechanisms of daily collateral valuation and margining, in crisis times these practices should be suspended temporarily to ensure the preservation of their moneyness through the crisis, thereby further contributing to the stabilization of market liquidity.

While actual asset purchases are the most powerful measure in a market liquidity crisis, timely adoption of countercyclical haircut changes may pre-empt such interventions by abating market liquidity strains before they erupt into crisis. Indeed, countercyclical haircut changes may be exactly the kind of performative signal that convinces markets that collateral asset purchases will follow if necessary.

We suggest that a modern version of Bagehot's principle should be dual. First, adopt countercyclical haircuts to signal that distressed government bonds will be considered "good securities" regardless of 
any looming collateral devaluation spirals and second, if this is not enough to abate market liquidity strains, engage in collateral asset purchases at a wide bid-ask spread. ${ }^{23}$

\section{3} Nyborg's critique of the ECB revisited

Let us briefly revisit Nyborg's critique of the ECB from the vantage point of the money view. The protracted nature of Europe's crisis, as compared with the sharper but shorter US crisis, was a result, we suggest, of the ECB's reluctance to support market liquidity by guaranteeing a floor to the collateral values of the core assets in European credit intermediation, that is, the government bonds of Eurozone member states. Where money view scholars see an ambivalent effort at stabilizing a liquidity crisis, Nyborg sees only an overly generous central bank encouraging governments and banks to engage in reckless borrowing. Nyborg doesn't reflect much on liquidity and hence fails to distinguish between funding and market liquidity. Although the particulars are specific to Nyborg, his analysis concords with a wider tendency of central banking scholarship; of not adequately "appreciating the liquidity dimension of the system" (Mehrling 2011: 129).

If the ECB had insisted on continuous readjustment of haircuts - aligning them with changing risk perceptions of market participants (as in Buiter and Siberts proposal), or in proportion with key indicators of fiscal performance (a la Nyborg) - even higher haircut differentials would have resulted. ${ }^{24}$ This, in turn, would have been detrimental to market liquidity in the government bond markets of distressed member states. The difference between insisting on a high haircut on a distressed government bond and refusing to accept it as collateral is mainly analytical. For all empirical purposes, the two will be one and the same in their effects. This is troubling, for as Bagehot noted, "if securities, really good and usually convertible, are refused by the Bank, the alarm will not abate, the other loans will fail in obtaining their end, and the panic will become worse and worse" (Bagehot 1873: 198-199).

Ironically, disciplinary haircuts would be detrimental not only to market liquidity, but also to central bank balance sheets, because the need for liquidity provision will be insatiable in a collateral policy regime that is systemically procyclical. Using haircuts on sovereign debts in a more generalized disciplinary logic would not have resolved the European sovereign debt crisis but rather have further deepened and prolonged it.

Beyond the specifics of the European case, we suggest that the main effect of adopting a regime of generalized disciplinary haircuts would be to cause collateral valuation spirals on the government bonds of sovereigns in fiscal distress, which in turn would affect the afflicted countries by likely causing a

\footnotetext{
${ }^{23}$ Against a potential objection that such practices would violate Bagehot's principle of providing liquidity but at "penalty rates", see the discussion section below.

${ }^{24}$ These two modalities of generalized fiscal disciplining may be seen as manifesting, respectively, an American-style neoliberal governmental rationality (Buiter and Sibert) and a German-style Ordo-liberal (Nyborg) one (see Vestergaard, 2009: 202-213).
} 
credit crunch and a depression of domestic demand, with negative ripple effects for production and employment across many sectors of the economy.

\section{DISCUSSION: ENGAGING WITH LIKELY OBJECTIONS}

Before we conclude, allow us to take on a few likely objections to the countercyclical collateral policies we are proposing: i) central banks cannot responsibly suspend their risk management practices, even if only partially and temporarily; ii) countercyclical haircuts would create highly detrimental moral hazard both with sovereigns and banks, and iii) such policies would constitute a fundamental violation of Bagehot's principle of only providing emergency liquidity at 'penalty rates'.

\subsection{Central bank risk management in crisis times}

The ECBs collateral policy during the crisis consisted in "striking a balance" between increasing the pool of assets eligible for credit operations with the ECB and increasing haircuts to safeguard the ECB balance sheet against the increased liquidity risk associated with lower collateral standards (Wolff 2013: 75):

the Eurosystem has... [been] expanding the eligibility criteria for collateral... in order to avoid widespread collateral constraints. At the same time, the Eurosystem has continued to regularly review its risk control measures in order to ensure that the Eurosystem continues to be adequately protected in a changing market environment, while still making sufficient eligible collateral available to banks (ECB 2013b: 2).

In the eyes of the ECB, the dual strategy of expanding asset eligibility and increasing haircuts was a necessary balancing act, in other words. We argue, however, that rather than being simply a necessity, to meet multiple objectives, the ECB's dual strategy has been at cross-purposes and largely self-defeating. Expanding the pool of assets that are eligible for ECB credit operations has the countercyclical effect that is needed to stem a market liquidity crisis. But to increase haircuts on the least liquid assets has the opposite effect. One measure is countercyclical, the other procyclical.

The notion that liquidity provision must trump standard risk management practices in a crisis is not a recent invention. Henry Thornton, one of the earliest central banking scholars, wrote in the early nineteenth century, that in crisis times "it would be better to expand [central bank] lending... rather than contract lending to defend its reserves" (Laidler 2003: 66). The more a central bank allows a risk management logic to guide its collateral policies in periods of market stress, the more injections of central bank money will eventually be needed to stay the crisis. Shortsighted risk management concerns undermine not just an effective handling of the liquidity crisis, but also inadvertently increase the risks that ends up on the balance sheet of the operating central bank, in and through the perpetual need for liquidity provision against lower-quality collateral.

With regard to liquidity crises and solvency, two things are well-known: first, that in a liquidity crisis it is not possible to clearly distinguish between illiquid and insolvent banks (Goodhart 1999; Le Maux 
2017; Freixas et al 2000) and second, that banks that were illiquid but solvent at the outset maybe easily become insolvent if the liquidity crisis is prolonged. The most effective policy against bank insolvencies hence is to cut the liquidity crisis as short as possible.

\subsection{Moral hazard?}

Countercyclical collateral policies as the ones advocated here are likely to be subject to standard criticism against measures that ease access to liquidity, namely that such policies cause moral hazard in relation to both governments and banks, who get access to funding on "subsidized" terms. Lowering haircuts on central bank liquidity would amount, in this framing, to an encouragement of "overborrowing" by banks and governments that might in fact be insolvent (and hence should not receive central bank funding).

Against such objections we hold that that it is necessary to "separate liquidity provision from moral hazard concerns" (de Grauwe 2011: 2). In much the same way as "it would be a terrible mistake if the central bank were to abandon its role of lender of last resort in the banking sector because there is a risk of moral hazard" (de Grauwe 2011: 2), we suggest that compromising collateral expansion by raising haircuts is an unfortunate strategy.

Even if moral hazard issues result from easing access to central bank liquidity, "there remains the question of the possible extent of loss" - if liquidity is not provided - "should there be a (contagious) systemic panic" (Goodhart 1999: 353). Put differently; to the extent that there is a moral hazard issue, it can be dealt with in more effective and conducive ways than by putting financial stability at risk.

The point is not that moral hazard problems should be ignored; only that they should be addressed in a different way and (possibly) by a different authority. "Liquidity provision should be performed by a central bank; the governance of moral hazard by another institution, the supervisor" (de Grauwe 2011: 2). The solvency of individual banks is a task for microprudential regulation and supervision, not a concern that should be held against collateral policies designed to ease a market liquidity crisis. ${ }^{25}$

Research has established that the moral hazard effects of central bank liquidity provision are less detrimental than those resulting from direct recapitalizations of banks, the dominant response to bank insolvencies. ${ }^{26}$ "[W]here liquidity support clearly can be separated from the provision of risk capital, the moral hazard created will be limited to possible mismanagement of liquidity risk", Freixas and colleagues argue, whereas "capital support... may raise expectations that the financial institution is insured against mismanagement of virtually all types of risk, including credit and market risk" (Freixas et al 2000: 73).

We surmise that this assessment of moral hazard resulting from liquidity provision can be analytically extended to countercyclical collateral policy. The upshot is that even if the objective is to reduce moral hazard issues in banks to largest possible extent, lowering haircuts likely will contribute positively: by

25 "A uniform remedy for many diseases", said Bagehot, "often ends by killing the patient" (cited by Le Maux 2021: 25).

26 "Failing banks more often are dealt with through the injection of capital rather than being liquidated" (Freixas et al 2000: 72). 
helping abate the liquidity crisis, incidences of banks becoming insolvent are reduced, and hence moral hazard in its severest form is minimized. ${ }^{27}$

\subsection{Bagehot revised}

Another likely objection to countercyclical collateral policy is related to a widespread misreading of Bagehot's work. Many hold that the rule Bagehot advocated for central banks engaging in a lender of last resort role (LOLR), was to "lend freely, against good securities, at a penalty rate". We note, however, that Bagehot did not refer to a "penalty rate". Bagehot argued that interest rates should be high relative to market prices in normal times, not that they should be punitive in a panic. In the words of Charles Goodhart:

"[S]ome commentators... claim that Bagehot proposed that LOLR should always be a 'penalty' rate; that is, at a rate higher than that available in the marketplace. This is not so. Certainly, the rate should be above that in effect in the market prior to the panic, but not necessarily above the contemporaneous market rate" (Goodhart 1999: $341)^{28}$

The same point has been made more recently from within the European central banking establishment. In the words of Ulrich Bindseil, Director General in the ECB, and his colleague, Luc Laeven:

"[t]he famous 'Bagehot principle' ... is often misunderstood as implying that the central bank should lend at terms that are less favorable than the market, even in a crisis. In fact, the opposite is true. Loan terms should be less favorable compared to normal times, but precisely because of market malfunction during a crisis they should be offered at below-market rates during a crisis" (Bindseil and Laeven, 2017:1) ${ }^{29}$

The issue of what corresponds to the principle of an interest rate higher than the pre-crisis market rate in today's market-based financial systems has been addressed by Perry Mehrling, as we've seen. When central banks backstop the values of core assets used by banks to obtain funding in money markets, "trading freely at a wide bid-ask spread, against good security in the money market and in the class of

\footnotetext{
${ }^{27}$ We note that the insistence on good collateral in Bagehot's rule is motivated precisely by an acknowledgement that there is no easy way of distinguishing between illiquid and insolvent counterparties (Le Maux 2017: 1062). In the absence of such clarity, central bank demands collateral to safeguard against credit and liquidity risks. "Bagehot is often glossed as if he had declared that a central bank in a financial crisis should lend to illiquid but not insolvent institutions.... [But] Bagehot did not say "illiquid but not insolvent". He said something more clever: that the central bank should be seen to be "freely advancing on what in ordinary times is reckoned a good security"... then "the alarm of solvent merchants and bankers will be stayed" (DeLong 2012: 22).

${ }^{28}$ Goodhart observes that the terms relating to the notion of a penalty is only used four times in Bagehot's Lombard Street and not once in relation to central bank interest rates (Goodhart 1999).

${ }^{29}$ To be fair, Bindseil and Laeven do use the term penalty rates, but (as demonstrated) they don't subscribe to the associated notion that this entails interest rates higher than market rates.
} 
good securities in the capital market", it amounts to the modern equivalent of Bagehot's high interest rates (Mehrling 2014: 110).

Our focus here, however, is not the bid-ask spread of market-making asset purchases, but the potential role of collateral policy in abating an impending liquidity crisis, potentially making market-making purchases obsolete. For our purposes, therefore, the main point is that Bagehot followed Thornton in stressing the importance of collateral expansion in tackling liquidity crises. As we've noted above, Bagehot stressed that if central banks refuse to accept as collateral securities that in normal times are "really good and usually convertible", then "the alarm will not abate, the other loans will fail in obtaining their end, and the panic will become worse and worse" (Bagehot 1873: 198-199). ${ }^{30}$ Since there is little but a fine line between raising haircuts on distressed collateral assets and making them ineligible in credit operations, we suggest that our proposal to lower haircuts and reduce haircut differentials to abate a liquidity crisis is essentially in accordance with the spirit of the work of both Walter Bagehot and Henry Thornton.

7

\section{CONCLUDING REMARKS}

When Buiter and Sibert noted that "our central bankers should earn their keep by acting as market makers of last resort", they stressed that "covering the central bank's posterior" is considerably less important "than preventing avoidable financial instability" (Buiter and Sibert 2007). While we agree with the importance of the proposed reversion of the hierarchy of policy goals - preserving market liquidity first, worrying about potential central bank losses later - a crucial point to appreciate is that the former objective calls for an inversion of the standard use of risk management tools.

For a central bank to combat a market liquidity crisis effectively, it must decrease haircuts, not increase them - and more so for assets with low ratings, such that haircut differentials narrow rather than widen. This is essential to market liquidity. ${ }^{31}$ Incidentally, it is also by far the best risk management strategy, because the need for liquidity injections and asset purchases will be much more speedily satisfied with this policy mix.

The ECBs ambivalent strategy - of providing liquidity but raising haircuts on distressed assets - did not amount to "lending freely, against any and all collateral that is good in normal times", as Bagehot's rule would imply (Bagehot 1873; Goodhart 1999; Humphrey 1989; Mehrling 2013a, 2013b). By expanding collateral eligibility but raising haircuts and haircut differentials, it was undermining the market liquidity it was trying to restore. To stop collateral valuation spirals, central banks must lower haircuts and haircut differentials - and suspend rather than follow the collateral valuation practices of financial markets. What

\footnotetext{
${ }^{30}$ We note that Bagehot's argument in favour of "high" or "very high" interest rates was never motivated by moral hazard concerns; see the discussion in Le Maux (2021: 20-22).

${ }^{31}$ Buiter and Sibert argue that it is essential to broaden collateral eligibility to accept assets that would otherwise be (temporarily) illiquid to combat a market liquidity crisis, but they don't discuss the potential role of haircut changes.
} 
Nyborg views as an erosion of market discipline - the temporary provision of liquidity against illiquid collateral - from a money view perspective is an indispensable financial stability tool.

In the terminology of Brunnermeier and colleagues, Nyborg is positioned on the Germanic side of the 'Rhine Divide' on matters of macrofinancial governance, characterized by an emphasis on solvency over liquidity issues (Brunnermeier et al 2016). The trouble is that in an era of market-based finance and in the context of a discussion of central bank practices, a solvency perspective offers more heat than light. ${ }^{32}$ While Nyborg's work brings to the fore an often overlooked aspect of central banking - the collateral eligibility and haircut rules that constitute the foundation of central bank credit operations - we have shown that Nyborg's work is problematic in three significant ways: first, it incorrectly claims that the ECB's collateral framework has little market input and therefore undermines market discipline and distorts resource allocation. Second, its suggestion that the ECB's haircut framework during the crisis was overly generous for governments in distressed member states is at odds with the fact that the ECB raised haircuts sharply for assets with low credit ratings. Last, but not least, the mode of disciplinary collateral policy that Nyborg advocates going forward would be procyclical and destabilizing.

These problems are inextricably intertwined with Nyborg's failure to distinguish between funding and market liquidity. If the objective of preserving market liquidity in crisis times drops below the radar, it is hardly surprising that policy prescriptions veer in a dysfunctional direction. No conceivable measure of market discipline can restore market liquidity in a collateral valuation spiral, nor prevent such dynamics being set in motion in the first place. We surmise that the European sovereign debt and bank crisis was only overcome when the ECB addressed it not as a funding liquidity crisis, but as a market liquidity crisis, committing to providing the needed elasticity to the system.

The appropriate collateral policy for a market liquidity crisis is an expansionary collateral policy. More specifically, central banks should adopt a collateral easing strategy consisting of three main elements; a broadening of collateral eligibility; a reduction of haircuts, and a narrowing (or temporary suspension) of haircut differentials.

In the ECBs pandemic response, it adopted the first of these policies, but not the other two; haircuts were increased markedly for lower-quality assets (Vestergaard and Gabor, 2019a). It is not unlikely that a temporary suspension of haircut differentials on government bonds would have rendered the need for persistent asset purchases to achieve the desired 'spread narrowing' (Krauss 2020) considerably smaller. Under the current regime of massive monthly asset purchases by the ECB, the dynamic effects of its higher haircuts for government bonds with a low credit rating are temporarily muted. But it is difficult to imagine that the phasing out of ECB asset purchases that will eventually come, can be orderly without a concomitant reduction of haircut differentials.

\footnotetext{
32 The emphasis on solvency is central but it does not fully account for Nyborg's position. There is a certain moralism and punitive logic to his arguments that not all peers on the Germanic side of the Rhine Divide would subscribe to.
} 


\section{REFERENCES}

Argitis, G. (2017). Evolutionary finance and central banking. Cambridge Journal of Economics, 41: 961976.

Bagehot, W. (1873). Lombard Street: A description of the money market. London: John Murray.

Bank of Canada (2011). Liquidity provision and collateral haircuts in payments systems, Bank of Canada Review, Autumn 2011.

Bank of England (2015). The resilience of financial market liquidity. Financial Stability Paper, No. 34, October 2015. London: Bank of England.

Bibow, J. (2013). At the crossroads: the euro and its central bank guardian (and savior?). Cambridge Journal of Economics, 37: 609-626.

Bindseil, U. (2005). Monetary policy implementation. Theory, past and future. Oxford University Press.

Bindseil, U. (2014). Monetary policy operations and financial systems. Oxford University Press.

Bindseil, U., (2019). Central bank digital currency: financial system implications and control. International Journal of Political Economy, 48(4): 303-335.

Bindseil, U. and Laeven, L. (2017). Confusion about the lender of last resort. Vox, 13 January, 2017.

Bini Smaghi, L. (2010), Monetary policy transmission in a changing financial system: lessons from the recent past, thoughts about the future. Speech given at Barclays Global Inflation Conference, 14 June 2010, New York.

BIS (2013). Central bank collateral frameworks and practices. Geneva: Bank of International Settlements.

BIS (2014). Rethinking the lender of last resort. BIS Papers, No 79, September 2014. Bank of International Settlements.

BIS (2015). Central bank operating frameworks and collateral markets. CGFS Paper, No 53. Committee of the Global Financial System, Markets Committee, Bank of International Settlements.

Boy, N. and Gabor, D. (2019). Collateral times. Economy \& Society, 48 (3): 295-314.

Brunnermeier, M. and Pedersen, L.H. (2009). Funding liquidity and market liquidity. Review of Financial Studies, 22 (6): 2201-2238.

Brunnermeier, M., James, H. and Landauer, J.P. (2016). The Euro and the battle of ideas. Princeton University Press.

Buiter, W.H. and Sibert, A. (2006). How the Eurosystem's open-market operations weaken financial market discipline (and what to do about it), in Fiscal Policy and the Road to the Euro, National Bank of Poland, Warsaw.

Buiter, W.H. and Sibert, A. (2007). The central bank as a market maker of last resort. Financial Times, 12 August, 2007. 
Campiglio, E., Dafermos, Y., Monnin, P., Ryan-Collins, J., Schotten, G., Tanka, M. (2018). Climate change challenges for central banks and financial regulators. Nature Climate Change, 8(6): 462-468.

Chapman, J, Chio, J, Molico, M. (2011). Central bank haircut policy. Annals of Finance, 7 (3): 319-348.

Chesney, M. (2018). A Permanent Crisis. The financial oligarchy's seizing of power and the failure of democracy. Springer.

Cheun, S., von Köppen-Mertes, I., and Weller, B. (2009). The collateral frameworks of the Eurosystem, the Federal Reserve System and the Bank of England and financial crisis turmoil. Federal Reserve Occassional Paper, 107. New Work.

DeLong, B. (2012). This Time, It Is Not Different: The persistent concerns of financial macroeconomics. Working Paper, University of Berkeley and NBER:

de Grauwe, P. (2011). The European Central Bank: lender of last resort in government bond markets? CESifo Working Paper Series, No. 3569:11.

Dooley, M. (2014). Can central banks be market makers of last resort?, in BIS (2014), Rethinking the lender of last resort. Bank of International Settlements.

Dow, S. (2017). Central banking in the twenty-first century. Cambridge Journal of Economics, 41: 15391557.

ECB (2000). Guideline of the ECB of 31 August 2000 on monetary policy instruments and procedures of the Eurosystem (ECB/2000/7)

ECB (2002). Main features of the repo market in the Euro area. Monthly Bulletin, October, pp. 45-67.

ECB (2008). Guideline of the ECB of 21 November 2008 on temporary changes to the rules relating to the eligibility of collateral (ECB/2008/18)

ECB (2010). Guideline of the ECB of 16 September 2010 amending guideline ECB/2000/7 on monetary policy instruments and procedures of the Eurosystem (ECB/2010/13)

ECB (2011). Guideline of the ECB of 20 September 2011 on monetary policy instruments and procedures of the Eurosystem (recast) (ECB/2011/4)

ECB (2012). Verbatim of the remarks made by Mario Draghi. Speech by Mario Draghi, President of the European Central Bank, at the Global Investment Conference in London, 26 July 2012. Available at: https://www.ecb.europa.eu/press/key/date/2012/html/sp120726.en.html

ECB (2013a). Collateral eligibility requirements: a comparative study across specific frameworks, July.

ECB (2013b). The Eurosystem Collateral Framework throughout the crisis, ECB Monthly Bulletin, July.

ECB (2013c). Decision of the ECB of 26 September 2013 on additional measures relating to Eurosystem refinancing operations and eligibility of collateral (ECB/2013/35).

ECB (2017a). What are haircuts. European Central Bank. Accessed 25 February 2017.

ECB (2017b). ECB introduces a new haircut schedule for marketable assets. European Central Bank.

ECB (2017c). The Eurosystem collateral framework explained. Occasional Paper Series, No 89. Frankfurt: European Central Bank. 
Eichengreen, B., El-Erian, M., Fraga, A., Ito, T., Pisani-Ferry, J., Prasad, E., Rajan, R., Ramos, M., Reinhart, C., Rey, H., Rodrik, D., Rogoff, K., Shin, H.S., Velasco, A., Weder di Mauro, B., Yu, Y. (2011). Rethinking central banking. Brookings Report.

Fiebiger, B. and Lavoie, M. (2021). Central bankers and the rationale for unconventional monetary policies: reasserting, renouncing or recasting monetarism? Cambridge Journal of Economics, 45: $37-$ 59.

Gabor, D. and Ban, C. (2016). Banking on bonds: the new links between states and markets, JCMS: Journal of Common Market Studies, 54 (3): 617-635.

Gabor, D. (2016). The (impossible) repo trinity. Review of International Political Economy, 23 (6): $967-$ 1000 .

Gabor, D. and Vestergaard, J. (2016). Towards a theory of shadow money. https://www.ineteconomics.org/uploads/papers/Towards_Theory_Shadow_Money_GV_INET.pdf

Giovanni Group (1999). EU repo markets: opportunities for change. October 1999, Brussels.

Goodhart, C.A.E. (1999). Myths about the lender of last resort. International Finance, 2 (3): 339-360.

Goodhart, C.A.E., Ertürk, I., Gabor, D., and Vestergaard, J. (2014). Central banking at a crossroads: Europe and beyond. Edward Elgar.

Hauser, A. (2021). From lender of last resort to market maker of last resort via the dash for cash: why central banks need new tools for dealing with market dysfunction. Speech given by Andrew Hauser, Executive Director of Markets, 7 January 2921, Bank of England.

Humphrey, T. (1989). Lender of last resort: the concept in history, Economic Review, 75 (2).

Fels, J. (2005a), "Life Without the Pact", Morgan Stanley, Global Economics, Economic Trends, January 24, 2005, pp.1-3.

Fels, J. (2005b), “Markets can punish Europe’s fiscal sinners”, Financial Times, 1 ${ }^{\text {st }}$ April 2005.

Fitoussi, J. (2005), "Fiscal Indiscipline: Why No Reaction Yet by Markets?", Briefing Notes to the Committee for Economic and Monetary Affairs of the European Parliament, Second Quarter, for discussion at the Meeting with Monetary Experts, 11 May 2005.

Krauss, M. (2020). The ECBs new stealth mandate. Project Syndicate, December 15, 2020.

Le Maux, L. (2017). Financial structure changes and the central bank policy. Journal of Economic Issues, vol LI (4): 1054-1073.

Le Maux, L. (2021). Bagehot for central bankers. INET Working Paper, No 147. New York: Institute for New Economic Thinking.

Le Maux, L. and Scialom, L. (2013). Central banks and financial stability: rediscovering the lender-oflast-resort practice in a finance economy. Cambridge Journal of Economics, 37: 1-16.

Mehrling, P. (2011). The New Lombard Street. Princeton University Press.

Mehrling, P. (2012). Three Principles for Market-Based Credit Regulation. American Economic Review 102 (3): 107-112. 
Mehrling, P. (2013a). "Insights from Walter Bagehot", in West and Whaples (eds.), The Economic Crisis in Retrospect: Explanations by Great Economists, pp 13-42. Elgar.

Mehrling, P. (2013b). "The inherent hierarch of money", in Taylor, Rezai, and Michl (eds.), Social Fairness and Economics: Economic Essays in the Spirit of Duncan Foley (pp. 394-404), Routledge.

Mehrling, P. (2014). Why central banking should be re-imagined, in BIS (2014), Rethinking the lender of last resort. Bank of International Settlements.

Mehrling, P. (2015). Discipline and Elasticity in the Global Swap Network. International Journal of Political Economy, 44 (4): 311-324.

Mehrling, P. (2016). Re-theorizing liquidity, in Desan (ed.), Inside money: liquidity as a matter of design.

Mehrling, P, Poszar, Z., Sweeney, J. and Neilson, D. (2014). Bagehot was a Shadow Banker: Shadow Banking, Central Banking and the Future of Finance, in Claessens, Evanoff, Kaufman and Laeven (eds.), Shadow Banking Within and Across Borders, World Publishing.

Nyborg, K. (2016). Central bank collateral frameworks. Research Paper Series, No 15-10, Swiss Finance Institute.

Nyborg, K. (2017). Collateral frameworks: The open secret of central banking. Cambridge University Press.

Orphanides, A. (2017). ECB monetary policy and Euro area governance: collateral eligibility criteria for sovereign debt. MIT Sloan Research Paper, No. 5258-17. MIT, Sloan School of Management.

Pozsar, Z. (2014). Shadow banking: The money view. OFR Working Paper, 14-04. New York: Office of Financial Research.

Sissoko, C. (2014). Shadow banking: why modern money markets are less stable than $19^{\text {th }}$ century money markets but should be stabilized by a 'dealer of last resort'. Research Paper, No. 14-21, Center for Law and Social Science, USC Gould.

Tucker, P. (2014). The lender of last resort and modern central banking: principles and reconstruction. BIS Papers, No. 79, September.

Van Bekkum, S., Gabarro, M. Irani, R.M. (2017). Does a larger menu increase appetite? Collateral eligibility and credit supply. Review of Financial Studies, 31 (3): 943-979.

Vestergaard, J., (2004). The Asian crisis and shaping of 'proper' economies. Cambridge Journal of Economics, 28 (6): 809-827.

Vestergaard, J., (2009). Discipline in the global economy? International Finance and the End of Liberalism. London: Routledge.

Vestergaard, J. and Gabor, D., (2019a). Collateral easing with disciplinary dysfunction? On the limitations of the ECBs Covid-19 response. FEPS Working Paper. Brussels: Foundation for European Progressive Studies.

Vestergaard, J. and Gabor, D., (2019b). Confronting the ECBs austerity mandate. FEPS Policy Brief. Brussels: Foundation for European Progressive Studies. 
Vestergaard, J. and Gabor, D., (2019c). Should central banks discipline governments? Caught between fiscal prudence and market liquidity. FEPS Working Paper. Brussels: Foundation for European Progressive Studies.

Winkler, A. (2014). The ECB as a lender of last resort: banks versus governments. LSE Financial Markets Group Special Paper, No. 228, February.

Wolff, G. (2014). Eurosystem collateral policy and framework: was it unduly changed? Bruegel Policy Contribution, 2014/14, November.

Wyplosz, C. (2005). Fiscal policy: institutions vs rules. National Institute Economic Review, No 19: 64-77. 